\title{
JUDGES, BEHAVIORAL SCIENTISTS, AND \\ THE DEMANDS OF HUMANITY
}

\section{ROBERT A. BURT $\dagger$}

When I clerked for David Bazelon in 1964-65, a large original version of a Peanuts cartoon, inscribed by Charles $M$. Schulz, was displayed on the wall in the Judge's inner chambers. In the first frame of the cartoon, Lucy van Pelt discovers her comic book torn and crumpled on the floor. In the second frame, with outrage written on her face, she confronts her brother Linus with the corpus delicti-and Lucy, you will recall, was never far from glowering outrage. She shouts, "Who did this to my comic book? Are you responsible for this?" Linus responds, "Am I responsible? That is a very difficult question."

For the next several frames of the cartoon, Linus elaborates on the difficulties. With his ever-present security blanket pressed against his face and his customary dreamy expression, Linus propounds a series of questions: "What is the meaning of responsibility? Is anyone truly responsible for his conduct? Is there such a thing as free will or is each of us driven by forces beyond our control?" Throughout this exposition, the outrage on Lucy's face mounts in intensity. Finally she explodes: she rolls up her tattered comic book and hits Linus on the head. In the final frame, Linusstunned and floored, his security blanket knocked from his graspsays sadly, "Her kind never understands."

There, we might say, was the trajectory of David Bazelon's judicial career; in his more somber moments, the Judge himself said something of the sort to me and to others. And there too is an encapsulated social history of the United States from 1954, when the Judge wrote the opinion in Durham $v$. United States, ${ }^{1}$ to 1972 , when the Durham experiment was abandoned in United States $v$. Brawner. ${ }^{2}$ In 1954 the Linuses of this country were speaking out,

† Alexander M. Bickel Professor of Law, Yale University; Chair, Board of Trustees, Judge David L. Bazelon Center for Mental Health Law; Law Clerk to Chief Judge David L. Bazelon, 1964-65.

1.214 F.2d 862, 874-75 (D.C. Cir. 1954) (holding that the defendant would not be criminally responsible if the defendant's unlawful act was the product of mental disease or defect).

${ }^{2} 471$ F.2d 969, 973 (D.C. Cir. 1972) (en banc) (holding that a person is not responsible for criminal conduct if at the time of such conduct, as a result of mental disease or defect, he lacks substantial capacity to appreciate the wrongfulness of his 
raising questions about the causes of social disorder-not only regarding criminal conduct but more generally about the role of racial, religious, ethnic, and economic conflicts in fomenting disorder. The premise of these Linus-like questions around 1954 was that if we could understand the deepest roots of this divisiveness, we might then find means for healing; we might ease-we might even transcend-many of these social conflicts. By 1972, however, in the wake of political assassinations, race riots, and our continued embroilment in the Vietnam War, American social discord had almost drowned out the voices of our Linuses, and the Lucy van Pelts-quick to anger, even quicker to punish, and prepared to use books only as aggressive weapons and not as instruments of understanding-had come into dominance.

In this essay, I want to identify some of the premises that guided the Linus-like questions that Judge Bazelon raised from the bench, and the reasons in particular that he tried to enlist behavioral scientists to join with him in this questioning. At the end of this brief inquiry, I will conclude-and hope you are persuaded-that the Judge's enterprise, his conception of his role as a judge, and the correlative role he saw for the behavioral sciences are as appropriate and important for 1994 as he believed they were in 1954.

In 1954 no one in American public life, whether on the bench or elsewhere, was more insistent on raising these questions or more intent on promoting processes of social healing than David Bazelon. But he was not alone in that year. It is not at all coincidental that in 1954, when Judge Bazelon wrote the Durham opinion, the Supreme Court decided Brown v. Board of Education. ${ }^{3}$ The underlying ambition and premises of both decisions were the same. The ambition was to transcend persistent, violent social conflict. The premises were: first, that mutual understanding among the warring parties was the key to achieving this ambition; second, that the judiciary had an important role in promoting this mutual understanding; and third, that the judiciary could enlist the assistance of behavioral scientists in this social healing enterprise.

Brown directly took on the problems of relations between Blacks and Whites, the legacy of slavery, a bloody, destructive civil war that ostensibly freed black people, and the succeeding segregation regime that re-enslaved them. Durham was not directly aimed at

conduct or to conform his conduct to the requirements of the law).

3347 U.S. 483, 495 (1954) (holding that racial segregation in the public schools denies black students equal protection). 
these problems: the defendant, Monte Durham, was a white man, and he was not charged with a violent crime; ${ }^{4}$ but a perceived link between crime and race relations was nonetheless the unspoken subtext of Durham, as these two elements were inextricably intertwined in popular understanding, especially in the District of Columbia, which in 1954 had the highest proportion of non-Whites in the population of any large American city. ${ }^{5}$

Durham was, of course, much more direct than Brown in enlisting behavioral scientists for its social healing purposes. The goal of Durham was to invite psychiatrists, in particular, to give testimony based on their own scientific discipline's understanding of human behavior, rather than through the presumed distortions of nineteenth-century legal categories in the traditionally formulated insanity defense. But behavioral science also played an important role in Brown. Although it is easy to overlook this role forty years afterward, the central legal problem in Brown was to identify the grounds for overruling the holding in Plessy v. Ferguson that "separate but equal" public facilities did not violate the equal protection guarantee of the Fourteenth Amendment. ${ }^{6}$ The Supreme Court ruled to the contrary in Brown, finding that "[s]eparate educational facilities are inherently unequal." It came to this legal conclusion, however, by denying that this was a question of law. The dispositive step-indeed the only step-in the Court's reasoning to support its finding of the inherent inequality of school segregation was this one sentence: "Whatever may have been the extent of psychological knowledge at the time of Plessy $v$. Ferguson, this finding is amply supported by modern authority." ${ }^{8}$ The Court then appended a footnote to this sentence, citing seven different contemporary studies by social scientists as the "modern authority" that supported its disapproval of Plessy. ${ }^{9}$

The Court was strenuously criticized for this invocation of scientific authority to support its conclusion. For our evaluative purposes today, we can ignore the segregationist complaints about "pointy-headed left-wing intellectuals" setting the Court's entire social agenda. We cannot, however, so quickly dismiss the criticism

4 See Durham, 214 F.2d at 864.

${ }^{5}$ See Bureau of the Census, U.S. Dept. of Commerce, Census of Population: 1950, CHARACTERISTICS OF THE POPULATION 1-139 to 1-140 (1953).

${ }^{6} 163$ U.S. 537, 548 (1896).

${ }^{7}$ Brown, 347 U.S. at 495 .

${ }^{8}$ Id. at 494.

${ }^{9}$ Id. at 494-95 n.11. 
from sympathetic observers that by relying on social scientists, the Brown Court obscured the moral basis for their condemnation of race segregation and appeared to treat the issue as technocraticthat is, properly resolved by experts alone-rather than democratic at its core. ${ }^{10}$ There is considerable force in this criticism. But the contemporaneous juxtaposition of Durham with Brown reveals a common underlying assumption in the two cases about the relationship between scientific expertise and moral judgment that is responsive to this criticism, if not fully exculpatory.

In Durham and in succeeding cases addressing the role of psychiatric testimony in insanity defense cases, Judge Bazelon was much more explicit and revealing regarding the relationship of scientific and moral judgment than the Supreme Court's compressed, cryptic citation in Brown. ${ }^{11}$ As the Judge saw it, properly formulated psychiatric testimony should give an account of the criminal defendant's psychological dynamic: what forces, one might say, arising from his "nature" (that is, his genetic endowments) and from his "nurture" (that is, his experiences in his family and cultural environments) might help to explain the origins of his behavior. ${ }^{12}$ This psychiatric testimony about the defendant was, according to Judge Bazelon, quite distinct from any moral judgment. ${ }^{13}$ The jury alone was entitled to reach a moral judgment; it, and it alone, would decide whether the defendant's conduct was morally blameworthy. ${ }^{14}$

Judge Bazelon never succeeded in enforcing this distinction in the insanity defense cases that appeared in his court from 1954 when Durham was decided until 1972 when Durham was abandoned. This was a source of enormous frustration to the Judge-the basic reason he finally declared the Durham experiment a "failure" and

${ }^{10}$ See generally Symposium, The Courts, Social Science, and School Desegregation, 39 LAW \& CONTEMP. PROBS., Winter/Spring 1975, at 1 (examining the effect on education of Brown and subsequent efforts at desegregation from the viewpoint of both legal scholars and social scientists).

$"$ See David L. BAZElon, Questioning AuthortTy: JuSTICE and Criminal LAW 49-70 (1988) (explaining the decision of the D.C. Circuit in Durham and analyzing its shortcomings).

${ }^{12}$ See id. at $60-61$.

${ }^{13}$ See id. at 49.

${ }^{14}$ See id. at 54 . In reaching this judgment, the jury would use the psychiatric testimony about the psychodynamic origins of the defendant's conduct; but this testimony was meant to offer, in effect, only the raw material on which a moral judgment would be based, and not to provide a moral judgment in itself. See id. 
one of the reasons, I believe, that he felt such a kinship with Linus, sitting stunned from his sister's blow and unhappy at her unwillingness or inability to understand. As the Judge saw it-quite justifiably, I believe-no matter how hard he tried, psychiatric witnesses still acted like Lucy van Pelt, inattentive to the complexities of human conduct and quick to reach punitive moral judgments, embedding these moralistic conclusions in psychiatric jargon about whether the defendant was "psychopathic" (thus "mentally ill and morally blameless") or "sociopathic" (and thus more "evil" than "ill"). (For those who are aficionados of Charles Schulz's work, you will remember that Lucy also served as the resident psychiatrist for the Peanuts gang; she would sit behind a kind of adapted curbstone lemonade stand, under a sign announcing that "the psychiatrist is in," and, in response to the accounts of human pain and error that Charlie Brown and the other patients would bring to her, she would dispense dismissive moralistic homilies.)

Lucy van Pelt, as well as the other psychiatrists who were "in," deserved Judge Bazelon's relentless criticism. A tension always existed, however, in the Judge's criticism of psychiatrists in insanity defense cases for their failure to distinguish between scientific and moral judgments. The tension arose not only because of the intrinsic difficulty of drawing this distinction, but because, I believe, the Judge himself considered the basic tenets of behavioral science not only consistent with but supportive of his deepest moral beliefs. In this sense, the Judge himself did not distinguish between scientific and moral judgments. Judge Bazelon was, moreover, not alone in this position; the Justices in Brown v. Board of Education invoked social science to condemn race segregation based on this same conviction that moral purpose and the science of human behavior were mutually reinforcing.

This conviction is based on the proposition that a scientific understanding of human conduct necessarily and naturalistically begins with the proposition that all human beings are fundamentally alike. In my view, this is a logically correct proposition. The human sciences posit that-notwithstanding the often vast differences in our endowments and capacities, in our personalities and conduct-each of us can properly be understood as members of the same human species whose essential nature develops according to the same natural rules.

Two different kinds of moral implications arise from this basic proposition. The first implication is that we can reach moral judgments about one another only if we begin with the descriptive 
scientific premise that we are fundamentally alike as a species. In other words, unless we can understand one another in the same terms, as members of the same species, we are simply mysterious and inaccessible to one another and have no basis for making comparative evaluative judgments of any sort. This implication does not, however, mean that because all human beings are fundamentally alike they are obliged, or even inclined, to like one another or approve of one another, or even treat one another with kindness rather than hostility. A naturalistic scientific understanding of human nature could start from the premise of fundamental similarity and yet come to the conclusion, for example, that each of us is fundamentally alike in being by nature avaricious and selfseeking and thus a constant threat to all others.

This was Thomas Hobbes's social scientific understanding of human nature. ${ }^{15}$ But Hobbes himself, the great progenitor of modern social science, drew a further implication from this understanding. He concluded that if human beings rationally understood and clearly acknowledged their naturally shared fundamental characteristic, they would draw the same normative conclusion; that is, they would construct a social organization to govern themselves in a way that would effectively curb their mutual hostility. ${ }^{16}$ Hobbes further argued that one normative conclusion in particular would follow from this scientific understanding-that mankind would understand that it could end its self-destructive warfare only by creating a sovereign to rule over everyone and be accountable to no one. ${ }^{17}$ This particular solution had little to commend itself for David Bazelon; he, as well as the Justices in Brown, however, did follow out the same logical pathway that Hobbes had marked four centuries earlier. Bazelon and the Justices in Brown believed that if human beings focused clearly and rationally on the descriptive scientific proposition that we are all fundamentally alike in our nature, then we would be more inclined

${ }^{15}$ See Thomas Hobbes, Leviathan (E.P. Dutton \& Co. 1950) (1651). Hobbes stated:

[B] ecause the condition of Man ... is a condition of Warre of every one against every one; in which case every one is governed by his own Reason; and there is nothing he can make use of, that may not be a help unto him, in preserving his life against his enemyes; It followeth, that in such a condition, every man has a Right to every thing; even to one anothers body. Id. at 107.

${ }^{16}$ See id. at 107-08.

${ }^{17}$ See id. at 143. 
to view one another with sympathy, with mutual understanding, and fellow feeling.

In the simplified, schematic way that I have sketched it, this position may seem naive and sentimental. In retrospect, viewed from the hardened social perspective of 1994, many of the common social beliefs generally held by Americans in 1954 may indeed appear so. In 1954 this country had just passed through two quite terrible and terrifying conflicts-the Great Depression and then the Second World War-and emerged socially more unified and economically stronger than even the wildest optimist would have predicted in the darkest days, say, of 1932. Against the backdrop of this harmonious ethos, there was no social conflict in the United States of 1954 that seemed inherently intractable-whether it was our historic racial divisions or the even more universal and longstanding struggles between rich and poor. So there may have been some naiveté, some excessive optimism, in the American zeitgeist of 1954, that led the Justices in Brown to demand that the country confront its racial conflicts, or that led Judge Bazelon in Durham to insist that the community, through its criminal juries, face the truth that criminal offenders were not a different breed of humanity but were products of the psychological and social forces that shape us all.

If there was some naivete here, however, there was nonetheless a greater measure of hardheaded realism in these judicial demands. In terms of believing in the possibility of harmonious social relations in this country, 1954 may have been one of a few high points in American history. But no one who had lived during the first half of the twentieth century-least of all David Bazelon, as I knew him-could be unaware of the potential for hatred and brutality in all human affairs. The Nazi Holocaust alone proved this point. The Holocaust also demonstrated the ease with which science can be enlisted in destructive social enterprises-not only, and not even principally, in the design of weapons of terrible force, but more insidiously in the justification on supposedly scientific grounds of the subordination and ultimate annihilation of some people by other people.

The central question for Judge Bazelon's generation-the question that remains as urgent for us today-is whether the depths of human brutality revealed by the Holocaust can be averted in social relations. Judge Bazelon's answer was that judges in particular have a unique preventative role to continuously warn us of our propensity toward mutually destructive cruelties, and that one way 
for judges to accomplish this role is to enlist behavioral scientists in emphasizing the proposition that all human beings are fundamentally alike. Judge Bazelon's answer also remains relevant to our time.

Many people today deny this relevance. These deniers, however, fail to understand that neither judges nor behavioral scientists can be, so to speak, "neutral" in this matter. These deniers do not realize that unless judges actively oppose the impulse toward oppressive brutality in social relations, they will inevitably find themselves enlisted as active agents of that brutality. The equivalent belief in scientific "neutrality" is similarly blind to the reality that behavioral scientists have only this same stark choice: as scientists, they can work either to avert or to promote this brutality, but they cannot exempt themselves from participating in one effort or the other.

The nineteenth- and early-twentieth-century history in this country of our treatment of mentally disabled people illustrates the truth of this proposition, both as it applied to behavioral scientists and to judges. In the early nineteenth century, when specialized social institutions were created for mentally disabled people, there were two different goals visibly at work: an individually focused recuperative or restorative purpose, to provide distinctive treatment in a sheltered environment for disabled people; and a socially focused purpose of protecting the "normal" world against the disruptive threats presented or imagined from "abnormal" people. ${ }^{18}$ These two goals always coexisted in the scientific and social rhetoric and practice that surrounded the specialized institutions for mentally ill and mentally retarded people. Yet increasingly throughout the nineteenth century, in both the social understanding and practical workings of these institutions, one of these two goals was emphasized-the social protective goal-ultimately to the virtual exclusion of the other, individual restorative goal. ${ }^{19}$

The result, in practical terms, was the confinement of an ever increasing number of people in ever larger-scale institutions. These people were, moreover, disproportionately drawn from vulnerable minority populations-recent immigrants and members of racial and ethnic minorities who were viewed with fear and aversion by the majority of "normal" Americans. Furthermore, the conditions in these institutions descended into such hellishly brutal conditions

18 See David Mechanic, Mental Health and Social Policy $51-55$ (1969).

${ }^{19}$ See id. at 53-54 (detailing the custodial purposes that guided treatment in a nineteenth-century mental hospital). 
that it seemed impossible to imagine that the institutions existed for any purpose except the infliction of torture for its own sake. Nevertheless, the behavioral scientists of the day continued to offer scientific rationales for the workings of these institutions. ${ }^{20}$

Some of this rhetoric was almost patently fraudulent, insofar as claims were made that individual inmates were therapeutically helped by these inflictions; but this kind of fraud was not the most insidious problem. The fundamental damage was done by scientists who justified the existence of these institutions based on claims that their inmates were intrinsically different from other, normal human beings. These claims were not clearly fraudulent. Differences could be observed between many mentally ill or retarded people and others; it was plausible in many cases to conclude that these differences were irrevocable and incurable. The proper question for the behavioral scientists was not whether these differences existed, but whether they should be underscored or instead whether the points of commonality or even potential commonality should be emphasized.

From a strictly scientific perspective, there was no clearly correct answer to this question. Although there are many commonalities between mentally "normal" and "abnormal" people, these commonalities are not necessarily more fundamental than the categorical differences that can be objectively observed and described. At the same time, neither is the existence of the differences the scientifically more fundamental characteristic. A scientist can choose one or the other emphasis; but-and here is the crucial point-the scientist must make one choice or the other, must emphasize commonality and correspondingly incline toward disregarding differences or vice versa.

Let me use a prosaic example to illustrate this proposition. Consider the old saw of the glass that is either half empty or half full. Viewed from some Olympian perspective, the truth is that this water glass is both half full and half empty. To add another such

${ }^{20}$ See Gerald N. Grob, The State and the Mentally Ill: A History of WORCESTER STATE HOSPITAL IN MASSACHUSETTS, 1830-1920, at 10 (1966) (explaining that the approach known as "moral treatment" involved the creation of a total social, physical, and psychological therapeutic environment); MECHANIC, supra note 18, at 51-56 (basing moral treatment on the assumption that psychiatric illness could be alleviated if the patient was treated in a consisteht and friendly fashion); DAVID J. ROTHMAN, THE DISCOVERY OF THE ASYLUM: SOCIAL ORDER AND DISORDER IN THE NEW REPUBLIC 109-29 (1971) (explaining the treatment of patients in these institutions as a vigorous attempt to promote the stability of the society). 
example, a pen-and-ink drawing that sometimes looks like a duck and sometimes looks like a rabbit is neither a duck nor a rabbit, but is truly a duck-rabbit. But our perceptual, cognitive capacity does not permit us to see both elements at the same time: if we see the glass as half full, we can see it half empty only by reorienting our perspective; if we see the duck, we cannot see the rabbit until we stop seeing the duck.

These perceptual examples have direct application in social perceptions. We may describe mixed emotions toward mentally ill or disabled people in the same breath-as ambivalence, both fear and pity, empathic identification and differentiated aversion. As a matter of general social perception, however, it is impossible, I believe, to truly feel both sides of this ambivalence at once; either side, if dwelled upon, tends to magnify itself and render the opposed perception increasingly out of reach, conceptually implausible, and impossible to imagine.

We can see exactly this social perceptual process at work in the response of judges in the late nineteenth and early twentieth centuries to claims regarding mentally ill or retarded people. By accepting and themselves underscoring a starkly differentiated social conception of disabled people, American judges fed the escalating social impulse toward brutalization. The high point of this judicial confirmation came in a 1927 Supreme Court opinion by Oliver Wendell Holmes, upholding compulsory sterilization of people with supposed genetically transmitted "feeble-mindedness." 21 In a nownotorious passage, Holmes justified this scientific policy in these terms:

We have seen more than once that the public welfare may call upon the best citizens for their lives. It would be strange if it could not call upon those who already sap the strength of the State for these lesser sacrifices .... It is better for all the world, if instead of waiting to execute degenerate offspring for crime, or to let them starve for their imbecility, society can prevent those who are manifestly unfit from continuing their kind. ${ }^{22}$

The embattled rhetoric of this passage is not incidental. Holmes portrays the struggle between the mentally normal and abnormal as a virtual war: we normal people must fight to ensure that we are not "swamped with incompetence." ${ }^{\text {"3 }}$ This imagery reflects the

${ }^{21}$ Buck v. Bell, 274 U.S. 200, 205 (1927).

${ }^{22} \mathrm{Id}$. at 207.

${ }^{23}$ Id. 
pervasive impact of the Civil War experience on Holmes and his contemporaries; ${ }^{24}$ from it, they thought they learned that all social relations are based on ceaseless hostility. This dark premise was the dominant guide for judicial conduct by the end of the nineteenth century at least until the Second World War-not only in judicial participation in institutional commitments for mentally disabled people and in approving sterilization laws, but more generally. ${ }^{25}$

The starkest examples can be seen in judicial review of general social regulation, especially in the Lochner line of decisions, in which the judges viewed labor-protective legislation as nothing more than class warfare that victimized employers, ${ }^{26}$ and in race matters epitomized by Plessy, in which judges approved the subordination of Blacks on the ground that equality was a chimerical goal in race relations, that because race warfare was inevitable, one race must always dominate the other. ${ }^{27}$ In all of these social relations, from the late nineteenth century well into the mid-twentieth century, we can see how the premise of fundamental hostility and the judicial endorsement of that premise led not simply to drawing sharp lines of differentiation-battle lines, in effect-between the contending parties (between Blacks and Whites, between labor and capital, and between mentally normal and abnormal people). We can also see the escalating brutalization of the vulnerable people on the disfavored side of those battle lines as evidenced by the lynchings and race riots, the spread of labor relations violence, and the horrendous "snake-pit" confinements of increasing numbers of mentally disabled people.

The linkage that I have identified between Durham and Brown in 1954 was thus not the first time in our history when a close connection could be seen in judicial attitudes toward racial

${ }^{24}$ See generally MaRk D. Howe, JUSTICE OLIVER Wendell HOLMES: The SHAPING YEARS, 1841-1870 (1957) (concluding that Holmes's Civil War experience dominated his later years). See also Saul Touster, In Search of Holmes from Within, 18 VAND. L. REV. 437, 437 (1965) (describing the "development of the Olympian aloofness, sentiment of honor, and disbelief in causes that characterized Holmes's later life").

${ }^{25}$ See Robert A. Burt, The Constitution In CONFlict 237-53 (1992). The Court was prompted by the Civil War experience in its fear of organized labor's disruptive power and its determination to protect employer property. See id.

${ }^{26}$ See, e.g., Adkins v. Children's Hosp., 261 U.S. 525, 561-62 (1923) (invalidating a minimum-wage law for women under the theory of freedom of contract); Coppage v. Kansas, 236 U.S. 1, 26 (1915) (holding that anti-"yellow dog" statutes violate due process by impairing the freedom of contract); Lochner v. New York, 198 U.S. 45, 64 (1905) (upholding the freedom of contract in the labor market).

${ }^{27}$ See Plessy v. Ferguson, 163 U.S. 537, 551 (1896). 
minorities and mentally disabled people. The only difference between 1954 and this earlier history is that in 1954 Judge Bazelon in Durham and the Justices in Brown chose to emphasize the possibility of harmonious relations rather than accentuate the prospect of endless hostilities. Judge Bazelon and the Brown Justices enlisted behavioral science for this social healing purpose rather than, as earlier judges had done, relying on behavioral scientists to patrol the ramparts by emphasizing differences between "normal" and "abnormal" human beings as battle lines between hostile combatants.

The Nazi experience in Germany brings all of this into even clearer focus. American attitudes toward racial conflict and the subordination of Blacks were explicitly invoked by German behavioral scientists to justify their own segregation and miscegenation laws directed against Jews. ${ }^{28}$ American sterilization practices in general, and Justice Holmes's constitutional approbation in particular, were explicitly cited by German physicians to justify, first, their mass sterilizations of mentally disabled people, and second, euthanasia-their purposeful killing of "useless eaters" who sapped the strength of the Reich-which in turn led, in a direct line, to the killing camps at Auschwitz. ${ }^{29}$ It is fashionable today to claim that the Nazi doctors and behavioral scientists were practicing "fraudulent science." But this is a glib and ultimately misleading account. $^{30}$ The racialist scientific efforts to identify differences in

${ }^{28}$ See Robert N. Proctor, Nazi Doctors, Racial Medicine, and Human Experimentation, in THE NAzI DOcToRs AND THE NUREMBERG CODE: HUMAN RIGHTS IN HUMAN EXPERIMENTATION 17, 23 (George J. Annas \& Michael A. Grodin eds., 1992). Proctor notes that

Nazi physicians on more than one occasion argued that German racial policies were relatively "liberal" compared with the treatment of blacks in the United States. . . . Nazi physicians spent a great deal of time discussing American miscegenation legislation; German medical journals reproduced charts showing the states in which blacks could or could not marry whites, could or could not vote, and so forth. . . . [Moreover, in] 1939, Germany's leading racial hygiene journal reported the refusal of the American Medical Association to admit black physicians to its membership; 5,000 black physicians had petitioned to join the all-white American body but were turned down. German physicians only one year before, in 1938, had barred Jews from practicing medicine (except on other Jews); Nazi racial theorists were thereby able to argue that Germany was "not alone" in its efforts to preserve racial purity.

Id. (footnote omitted).

${ }^{29}$ See id. at 21-25.

${ }^{30}$ See Mario Biagioli, Science, Modernity and the "Final Solution," in ProbING THE LIMITS OF REPRESENTATION: NAZISM AND THE "FINAL SOluTION" 185, 185 (Saul 
intelligence or skull dimensions or nose shapes may have been fools' errands, and may even have been bolstered by falsified data. But there surely are observable genetic differences among racial groups (such as the concentration of the gene for Tay-Sachs disease among Eastern European Jews, or for sickle cell anemia among Blacks). The question is not whether these scientific differentiations are fraudulent; it is whether we choose to make them relevant for any social purpose, whether these differences should be emphasized or submerged by accentuating human commonalities more than differences. ${ }^{31}$

American society today has virtually abandoned the fundamental principle enunciated forty years ago by Judge Bazelon in Durham and the Supreme Court in Brown. Today, the dominant voices in our judicial, as well as our political, institutions emphasize human differences more than commonalities; and this divisive behavior is based on the premise that social hostility is widespread and incorrigible, that harmonious social relations among differing groups cannot reliably be achieved. A radical change in attitude toward the criminal justice system is among the most striking indicators of this stark difference between the social ethos of 1954 and 1994. Today there is virtually no one on the ideological spectrum from left to right who maintains, as Judge Bazelon insisted, that the goal of rehabilitating criminal offenders is a critically important systemic ideal. Judge Bazelon was intensely critical of our shortcomings in implementing this ideal and of the hypocrisy and brutality practiced in the supposed service of this ideal; but despite these shortcomings, neither he nor those whose voices were dominant in legal institutions in the 1950s was prepared to abandon the pursuit of this ideal.

In sharp contrast, the rehabilitative ideal has been virtually abandoned today as a goal of the criminal justice system. ${ }^{32}$ Since 1970 our federal and state prison population has more than tripled; we have the highest rate of incarceration in the entire world and the length of our prison terms, as well as the numbers of prisoners, is increasing at a higher rate than in any other country in the world. ${ }^{33}$ The significance of these statistics is indicated by our

\footnotetext{
Friedlander ed., 1992).

31 For a sensitive, extended exploration of this proposition, see MARTHA MINOW, MAKING ALL THE DIFFERENCE: INCLUSION, EXCLUSION, AND AMERICAN LAW (1990). ${ }^{32}$ See generally Robert A. Burt, Cruelty, Hypocrisy, and the Rehabilitative Ideal in Corrections, 16 INT'L J.L. \& PSYCHIATRY 359 (1993).

${ }^{33}$ See NORVAL MORRIS \& Michael H. TONRY, BETWEEN PRISON AND PROBATION:
} 
current romantic obsession with the death penalty: the premise that criminal offenders are not simply different from law-abiding citizens, but that they are so different as to stand altogether outside the bounds of humanity. The justification typically offered for this judgment is that the criminal offenders themselves have treated their victims as less than human, as expendable. This may be true, and the impulse toward retaliatory inflictions may accordingly be intensely felt. But if "they"-the criminal element-treat "us" as expendable and we in turn treat them as less than human, it is hard to see how this cycle of inhumane infliction is ever interrupted. All of the evidence $I$ can see indicates that in these retaliatory inflictions, everyone-both the good guys and the bad guys-becomes trapped in an escalating contest of brutalizing inhumanity. ${ }^{34}$

Those who argue for the use of the death penalty or for longer prison terms can point to real, observable differences between criminal offenders and peaceable people. Among these advocates are behavioral scientists who will testify to the ineradicability of these differences and judges who, based on this testimony, are prepared to expel offenders from membership in the human race. I disagree with these scientists and judges. The choice in these matters, however, is not between truth and falsehood in behavioral science; nor is it between a true and false interpretation of a judge's constitutional role. Scientists can justify accentuating the differences among people as well as emphasizing human commonalities. Our constitutional tradition, both in its origins and in its successive interpretations, provides precedent for judicial conduct that approves policies of differentiation and subordination as expressions of social hostility, as well as judicial conduct that gives clear preference to equality, that is, to essentially undifferentiated status based on a vision of shared humanity. Neither of these positions is provably false, but one of them is ultimately and terrifyingly dangerous.

Judge Bazelon saw the dangers that arise when judges and scientists, acting together or alone, endorse differentiation and subordination of one human being by another. He also saw that a contrary conception of the judicial role or of the uses of science offers no guarantee of social harmony. Yet he understood that

INTERMEdiate PUNiShMENTS IN A RATIONAl SENTENCING SySTEM 47 (1990); David J. Rothman, The Crime of Punishment, N.Y. REv. Books, Feb. 17, 1994, at 34, 34.

${ }^{34}$ See Robert A. Burt, Democracy, Equality, and the Death Penalty, THE RULE OF LAW: Nomos XXXVI, at 80, 90-97 (Ian Shapiro ed., 1994). 
unless judges and scientists alike emphasize our human commonalities-unless they emphasize the underlying social and psychological forces that can promise to draw us together-then we will be fated to drive one another further and further apart.

The apostles of organized social violence-of the death penalty, and of merely custodial confinement of "abnormal" people in prisons or mental institutions-offer a prospect of social harmony in the guise of victory by the forces of good over the forces of evil, of the "peace forces" over the "criminal forces." The only peace that can ever come by this route, however, is the leveled exhaustion of the bloodied battlefield, the silence of the graveyard, the ashes of the crematorium. This is the state that follows from the battle cries of the Lucy van Pelts of this world. In these battles, the Linuses among us sometimes are knocked to the sidelines. But, as David Bazelon's career attests, the hardiest souls get up again, to raise their disturbing questions and to warn us of the consequences of refusing to search for understanding. Judge Bazelon understood that if you are not part of this solution, then you-as a judge, as a behavioral scientist, and as a citizen-are part of the problem. Of this we can be sure: David Bazelon was not part of the problem. We should return to his mission. 


\section{FROM THE EDITORS}

Professor Susan Sturm commented on Professor Robert Burt's Article at the Bazelon Conference. After reviewing Professor Sturm's written version of her remarks, Professor Burt sent her a letter, dated September 8, 1994. Rather than responding in a letter, Professor Sturm revised her commentary to take the letter into account. The professors agreed that publishing the original version of Professor Sturm's commentary was unnecessary. To assist the reader, the Editors have added citations to Professor Burt's letter. 